\title{
酵母及び細菌を単独又は混合接種した魚介類における 揮発性塩基窒素の経日変化*1
}

(昭和 63 年 6 月 20 日受理)

\author{
小畠満子苂 外海泰秀*3 \\ 小林加代子*2 伊藤誉志男*3
}

\section{Time Courses of Total Volatile Basic Nitrogen (TVB-N) in Seafoods Inoculated Singly or as Mixtures with Spoilage Yeasts or Bacteria}

\author{
Michiko Kobatake ${ }^{* 1}$, Yasuhide TonogaI ${ }^{* 2}$, Kayoko Kobayashi ${ }^{* 1}$ and Yoshio Ito*2 \\ (*1) National Institute of Hygienic Sciences: 1-18-1, Kamiyoga, Setagaya-ku, Tokyo, Japan; \\ *2National Institute of Hygienic Sciences, Osaka Branch: \\ 1-1-43, Hoenzaka, Higashi-ku, Osaka, Japan)
}

Previously, we reported on the amount of T-VBN produced by yeasts or bacteria. Candida lipolytica produced the largest amount of T-VBN among the 5 yeast species tested, while Staphylococcus epidermidis produced the smallest amount, and Pseudomonas fluorescens produced the largest amount among the 4 bacterial species tested. In this paper, the microbiological and chemical changes of these 3 species were compared. C. lipolytica, S. epidermidis and $P$. fluorescens were inoculated singly or as mixtures into 3 different kinds of sterile seafood homogenate (common mackerel, black tiger shrimp and neon flying squid), and incubated at either 5,15 or $25^{\circ} \mathrm{C}$. The time courses of viable counts, $\mathrm{pH}$ values, and TVB-N values determined according to the microdiffusion method of Conway were observed for up to 7 days

(1) Viable counts: The growth curves of $C$. lipolytica at 15 and $25^{\circ} \mathrm{C}$ showed gradual slopes, and reached the stationary phase on day 7 . The growth curves of $P$. fluorescens and a mixture containing C. lipolytica, S. epidermidis and P. fluorescens at 15 and $25^{\circ} \mathrm{C}$ reached the stationary phases on day 2 . The growth curves of S. epidermidis at 5 and $15^{\circ} \mathrm{C}$ were lower than those of $C$. lipolytica, $P$. fluorescens and a mixture of all three.

(2) $\mathrm{pH}$ : The $\mathrm{pH}$ values in the seafood homogenate inoculated with $C$. lipolytica, $P$. fluorescens and a mixture of all three increased with temperature and duration of incubation.

( 3 ) TVB-N: Whereas the viable counts at $25^{\circ} \mathrm{C}$ of $C$. lipolytica were less than those of $P$. fluorescens, S. epidermidis and the mixture, the production of TVB-N by $C$. lipolytica was at almost the same levels as those of $P$. fluorescens and the mixture, and considerably more than that of $S$. epidermidis. The results of the previous and present experiments have thus confirmed that the yeasts produced the same spoilage phenomenon as the bacteria.

(Received June 20, 1988)

Key words: Candida lipolytica; Staphylococcus epidermidis; Pseudomonas fuorescens; 魚介類 seafood; $\mathrm{pH}$ 值 $\mathrm{pH}$ value; 堌殖曲線 growth curve; 総揮発性塩基窒素 total volatile basic nitrogen (TVB-N); 生菌数 viable counts

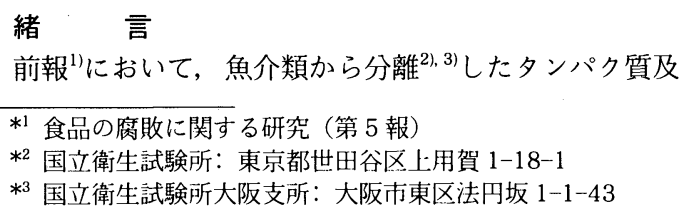

*2 国立衛生試験所：東京都世田谷区上用賀 1-18-1

*3 国立衛生試験所大阪支所：大阪市東区法円坂 1-1-43

び脂肪分解能陽性酵母 Candida lipolytica, C. sake, Cryptococcus laurentii, Trichosporon cutaneum, Tr.

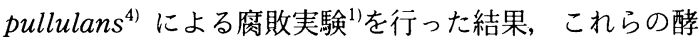
母は揮発性塩基窒素を生成し，細菌之同様な腐敗現象を 起こすことを報告1),5) した。 
本報では，前報1の腐敗実験に用いた醅母 5 菌種の中 で揮発性塩基窒素の生成量が最む多かった C. lipolytica と, 細菌 4 菌種の中で生成量が最も多かった P. fluorescens, 最も少なかった S. epidermidis の 3 菌種を滅菌魚 介類ホモジネートに単独または混合接種し， $5^{\circ}, 15^{\circ}$, $25^{\circ}$ で 1 週間保存した場合の生菌数, $\mathrm{pH}$ 值, 揮発性塩基 窒素量を経日的に測定した。また混合接種 1 週間保存に おける各 3 菌種の生育状態を調べるとともに，混合接種 3 週間保存後の各菌種の生残菌数をも測定し，相互の関 連性について検討した。

\section{実験方法}

1. 供試試料

市販の生鮮マサバ，冷凍ウシエビ（ブラックタイガー シュリンプ)，冷凍ムラサキイカを用いた。

2. 供試菌株

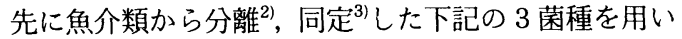
た.

Candida lipolytica M-20-P-5 NHL 11027, Pseudomonas fluorescens S-1 NHL 11074, Staphylococcus epidermidis S-6 NHL 11076

\section{3. 滅菌魚介類ホモジネートの調製}

前報1と同様に調製した。隇菌ホモジネートの量は各 $50 \mathrm{~g}$ とした.

\section{4. 供試菌株の接種及び培養}

前報”の実験方法 4 と同様な方法で C. lipolytica，S. epidermidis, P. fluorescens の接種菌液を調整した. C. lipolytica は $5.0 \times 10^{4} / \mathrm{g}$, S. epidermidis は $3.6 \times 10^{4} / \mathrm{g}$, P. fluorescens は $3.2 \times 10^{4} / \mathrm{g}$ の菌数でサバ, エビ, イカ の 3 種滅菌ホモジネート (以下サバ, エビ, イカと略記) にそれぞれ単独で， あるいは 3 菌種を混合して $(1.2 \times$ $\left.10^{5} / \mathrm{g}\right)$ 接種し, 滅菌スパーテルで無菌的に摼拌した後,

$5^{\circ}, 15^{\circ}, 25^{\circ}$ で保存した。

すなわち単独接種は 3 菌種別, 3 種魚介類別, 3 種保 存温度別に合計 27 種類の試料を 7 日間保存した。混合 接種は 3 種魚介類別, 3 種保存温度別に, 合計 9 種類の 試料を 3 週間保存した.

\section{5. 保存試料の採取}

単独接種及び混合接種合計 36 種類の三角フラスコ办 ら無菌的に保存 $0,2,4,7$ 日目に各 $1 \mathrm{~g}$ を生菌数測定用 として, 各 $2 \mathrm{~g}$ を官能試験用及び $\mathrm{pH}$ 测定用として, 各 $3 \mathrm{~g}$ を揮発性塩基窒素 (以下 VBN と略記) 測定用として 採取した. また混合接種の 9 種類の三角フラスコから保 存 3 週間後に, 各 $1 \mathrm{~g}$ を生菌数測定用として採取した.

\section{6. 生菌数測定}

食品衛生検查指針 ( I $)^{6}$ の生菌数測定法に準拠した。 生菌数測定のための培地は, 酵母用として YM 寒天培地 (Difco) を，また細菌用として生菌数測定用標準寒天培 地 (栄研化学(株)製) を使用し, 培養は酵母, 細菌とあ に $25^{\circ} ， 4$ 日間とした。
混合接種試料の同一希釈段階の希釈液 $0.1 \mathrm{ml}$ を各々 YM 寒天平板と標準寒天平板に塗抹した. YM 寒天平板 上に出現した白色大型のコロニーを測定して C. lipolytica の生菌数とした，標準寒天平板上の S. epidermidis と P. fluorescens のコロニーを別々に測定した. このよ うにして測定した 3 菌種単独の各生菌数数値を合計し て混合接種による保存試料の総菌数数值とした。

\section{7. 污染微生物確認試験}

前報1)之同梯な方法で接種菌以外の污染微生物の有無 を確認した。

\section{8. $\mathrm{pH}$ の測定}

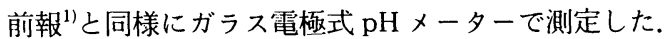

\section{VBN の定量}

前報1 ${ }^{1}$ と同様にConway の微量拡散法 ${ }^{77,8)}$ により定量 した.

\section{実 験 結 果}

\section{1. 污染微生物確認試験}

一週間保存後の 36 種類，及び 3 週間保存後の 9 種類 の試料には接種菌以外の污染微生物は認められなかっ た.

\section{2. 対照実験}

サバ，エビ，イカの対照 VBN 值はそれぞれ 9.1, 12.1, $9.7 \mathrm{mg}-\mathrm{N} / 100 \mathrm{~g}$, 対照 $\mathrm{pH}$ 值はそれぞれ $\mathrm{pH}$ 5.7, pH 6.8, $\mathrm{pH} 6.6$ であった。これらの值は $5^{\circ}, 15^{\circ}, 25^{\circ}$ 保存の 7 日 後においてもほとんど変化しなかった。

\section{Candida lipolytica NHL 11027 単独接種}

本菌をサバ，エビ，イカに接種し， $5^{\circ}, 15^{\circ}, 25^{\circ}$ で 7 日 間保存した場合の VBN 值を Fig. 1, A に, pH 值を Fig. 1, B に，増殖曲線を Fig. 1, C に示した.

VBN：サバにおける 5 保存 7 日目の VBN 值は, 初期 腐敗値の目安とされている $30 \mathrm{mg}-\mathrm{N} / 100 \mathrm{~g}$ をやや上回 り, $32.7 \mathrm{mg}-\mathrm{N} /$ サバ $100 \mathrm{~g}$ となった. $15^{\circ}$ 保存では 4 日 目に $37.5 \mathrm{mg}-\mathrm{N} /$ サバ $100 \mathrm{~g}, 7$ 日目には初期腐敗值を はるかに越え $149.3 \mathrm{mg}-\mathrm{N} /$ サバ $100 \mathrm{~g}$ となった。 $25^{\circ}$ 保 存における VBN 值は経日的に著しく增加し，2, 4, 7 日 目でそれぞれ $32.7,112.0,260.0 \mathrm{mg}-\mathrm{N} /$ サバ $100 \mathrm{~g}$ と高 い值を示した. サバ, エビ, イカの魚種別による VBN 値 は近似していた。

$\mathrm{pH} ５^{\circ}$ 保存ではほとんど変化しなかったが，15及び $25^{\circ}$ 保存におけるサバ，エビ，イカの $\mathrm{pH}$ 值は経日的に 上昇し， 7 日目には $\mathrm{pH} 7.5 \sim 8.1$ となった。

増殖曲線： $5^{\circ}, 15^{\circ}, 25^{\circ}$ 保存で緩やかな曲線を示した。 サバにおける $5^{\circ}$ 保存 2 日目の酵母数は $2.5 \times 10^{5} \mathrm{cfu} / \mathrm{g}$ (以下 $\mathrm{cfu} / \mathrm{g}$ を略), 7 日目には, $3.4 \times 10^{6}$ となった. $15^{\circ}$ 保存では, $2,4,7$ 日目でそれぞれ $1.6 \times 10^{6}, 1.3 \times 10^{7}, 5.7$ $\times 10^{7}$ と増加した. $25^{\circ}$ 保存であ $15^{\circ}$ 保存とほとんど同 様な増殖曲線を示し，7 日目にはほぼ定常期に達した。 

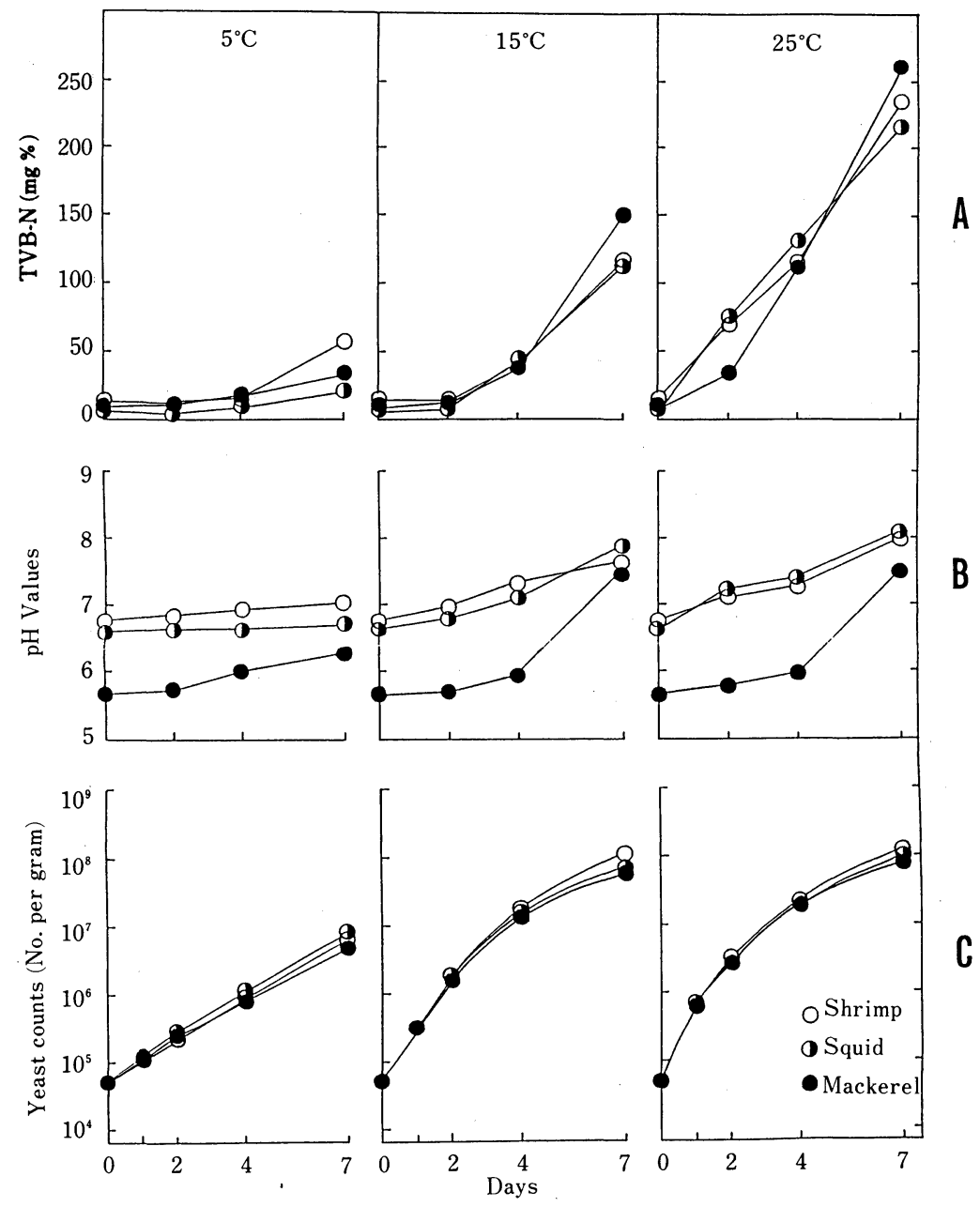

B

C

Fig. 1. Time courses of yeast counts, $\mathrm{pH}$ values, and TVB-N values in 3 kinds of seafood samples inoculated with C. lipolytica, and incubated at 5,15 and $25^{\circ} \mathrm{C}$ for up to 7 days.

A: TVB-N; B: $\mathrm{pH}$ values; C: yeast counts

\section{Staphylococcus epidermidis NHL 11076 単独} 接種

本菌をサバ，エビ，イカに接種し， $5^{\circ}, 15^{\circ}, 25^{\circ}$ で 7 日 間保存した場合の VBN 值を Fig. 2, A に, pH 值を Fig. 2, B に，増殖曲線を Fig. 2, C に示した.

VBN： 5 及び $15^{\circ}$ 保存におけるサバ，エビ，イカの VBN 值は極めて低く，いずれも初期腐敗值以下であっ た. $25^{\circ}$ 保存ではエビの VBN 值が経日的に増加した。腐 敗エビから分離した本菌による VBN 生成値は，サバ及 びイカよりはエビでやや高い值を示した。

$\mathrm{pH}: 5^{\circ}$ と $15^{\circ}$ 保存では変化しなかった. $25^{\circ}$ 保存では エビとイカの $\mathrm{pH}$ 值が経日的に上昇し， 7 日目には $\mathrm{pH}$ 7.9〜8.0 となったが, サバではやや下降した.

増殖曲線： 5 保存では接種菌は增殖しなかったが, $15^{\circ}$ 保存では 7 日目に $10^{8}$ となった. $25^{\circ}$ 保存では, 2 日 目に定常期に達した. 生菌数は土ビで最も多く, イカ, サバの順であった。

\section{Pseudomonas fuorescens NHL 11074 単独接種}

本菌をサバ，エビ，イカに接種し， $5^{\circ}, 15^{\circ}, 25^{\circ}$ で 7 日 間保存した場合の VBN 值を Fig. 3, A に, pH 值を Fig. 3, B に，増殖曲線を Fig. 3, C に示した.

VBN：サバにおける $5^{\circ}$ 保存 7 日目の VBN 值は 65.3 mg-N/サバ $100 \mathrm{~g}$ であった。1 $15^{\circ}$ 保存では経日的に漸次 増加し，25保存では，2，4，7 日目でそれぞれ 74.5, 174.7, $283.3 \mathrm{mg}-\mathrm{N} /$ サバ $100 \mathrm{~g}$ と著しく増加した.

$\mathrm{pH} ５^{\circ}$ 保存ではわずかに上昇した. $15^{\circ}$ 及び $25^{\circ}$ 保存 におけるサバ，エビ，イカの $\mathrm{pH}$ 值は経日的に上昇し， 7 日目には $\mathrm{pH} 8.0 \sim 8.5$ となった。 

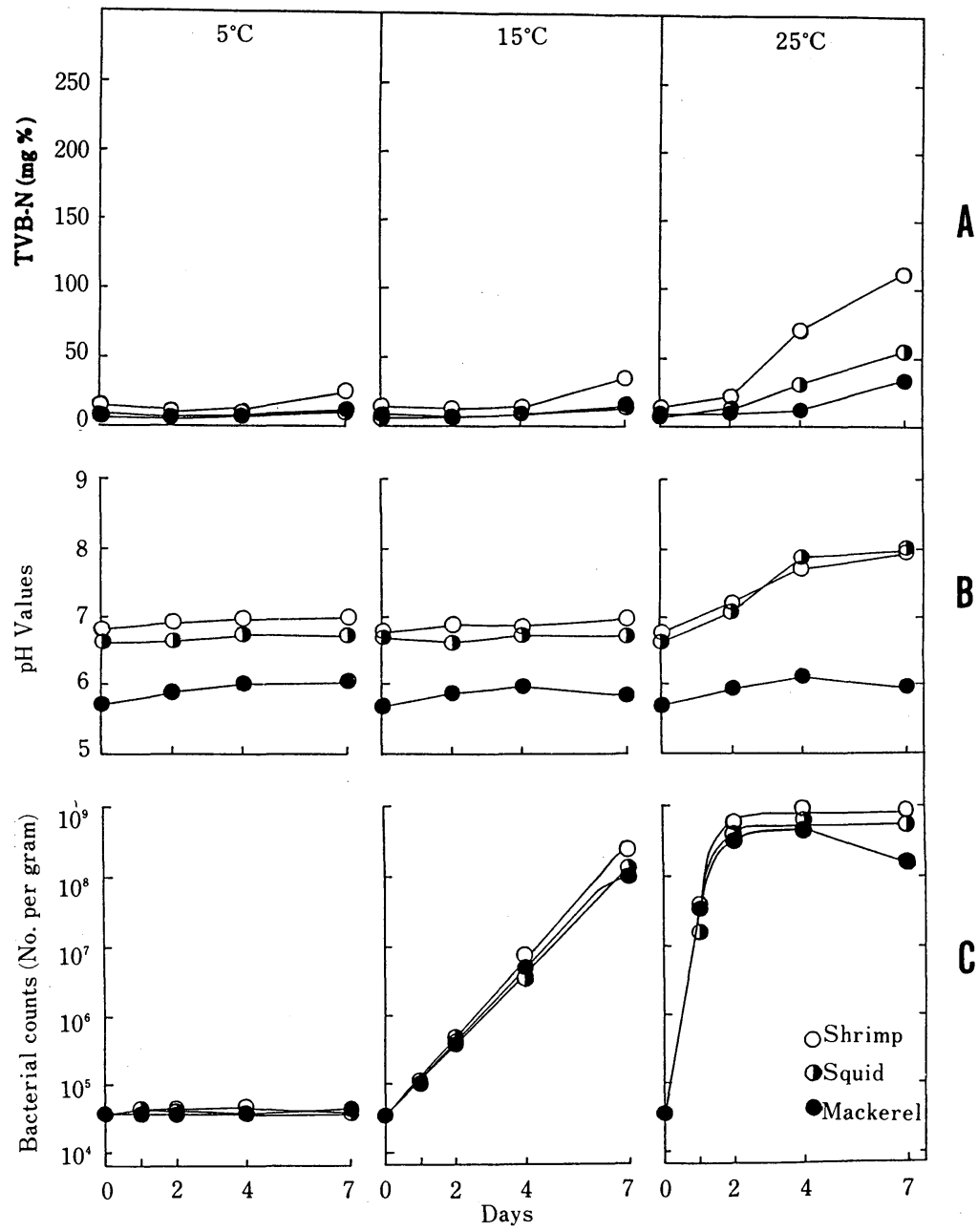

Fig. 2. Time courses of bacterial counts, $\mathrm{pH}$ values, and TVB-N values in 3 kinds of seafood samples inoculated with $S$. epidermidis, and incubated at 5,15 and $25^{\circ} \mathrm{C}$ for up to 7 days.

A: TVB-N; B: pH values; C: bacterial counts

増殖曲線： $5^{\circ}$ 保存では 7 日目に $10^{8}$ となった. $15^{\circ}$ 及 び $25^{\circ}$ 保存では増殖が速く，2 日目に定常期に達した. 腐敗サバから分離した本菌の生菌数は, エビとイカより はサバにおいてやや高い值を示した。

\section{C. lipolytica, S. epidermidis, P. fuorescens 混 合接種}

3 菌種を混合してサバ，エビ，イカに接種し， $5^{\circ}, 15^{\circ}$, $25^{\circ}$ で 7 日間保存した場合の VBN 值を Fig. 4, A に, $\mathrm{pH}$ 值を Fig. 4, B に，総菌数による増殖曲線を Fig. 4, C に，また各 3 菌種別の増殖曲線を Fig. 5 に示した。

VBN：サバにおける $5^{\circ}$ 保存 7 日目の VBN 值は 46.7 $\mathrm{mg}-\mathrm{N} /$ サバ $100 \mathrm{~g}$ であった. $15^{\circ}$ 保存では経日的に暫時 増加し, $25^{\circ}$ 保存では $2,4,7$ 日目でそれぞれ 37.5, 116.7, $229.0 \mathrm{mg}-\mathrm{N} /$ サバ $100 \mathrm{~g}$ と著しく増加した。
$\mathrm{pH} ５^{\circ}$ 保存ではわずかに上昇した. $15^{\circ}$ 及び $25^{\circ}$ 保存 におけるサバ，エビ，イカの $\mathrm{pH}$ 值は経日的に上昇し， 7 日目には $\mathrm{pH} 7.7 〜 8.3$ となった.

総菌数による増殖曲線： $5^{\circ}, 15^{\circ}, 25^{\circ}$ 保存における各 増殖曲線は, P. fuorescens 単独接種のそれらと類似し ていた。

3 菌種別の増殖曲線：混合接種，1 週間保存における 各 3 菌種別の増殖曲線のうち, $5^{\circ}, 15^{\circ}, 25^{\circ}$ 保存での $C$. lipolytica の増殖曲線 (Fig. 5, E) は, Fig. 1, C に示した C. lipolytica 単独接種の増殖曲線と類似しており，また P. fluoresecens の増殖曲線 (Fig. 5, D) は, Fig. 3, C に示 した P. fluorescens 単独接種の增殖曲線と類似してい た. しかし, S. epidermidis の増殖曲線 (Fig. 5, F) は $25^{\circ}$ 保存では, Fig. 2, C に示した S. epidermidis 単独接種の 


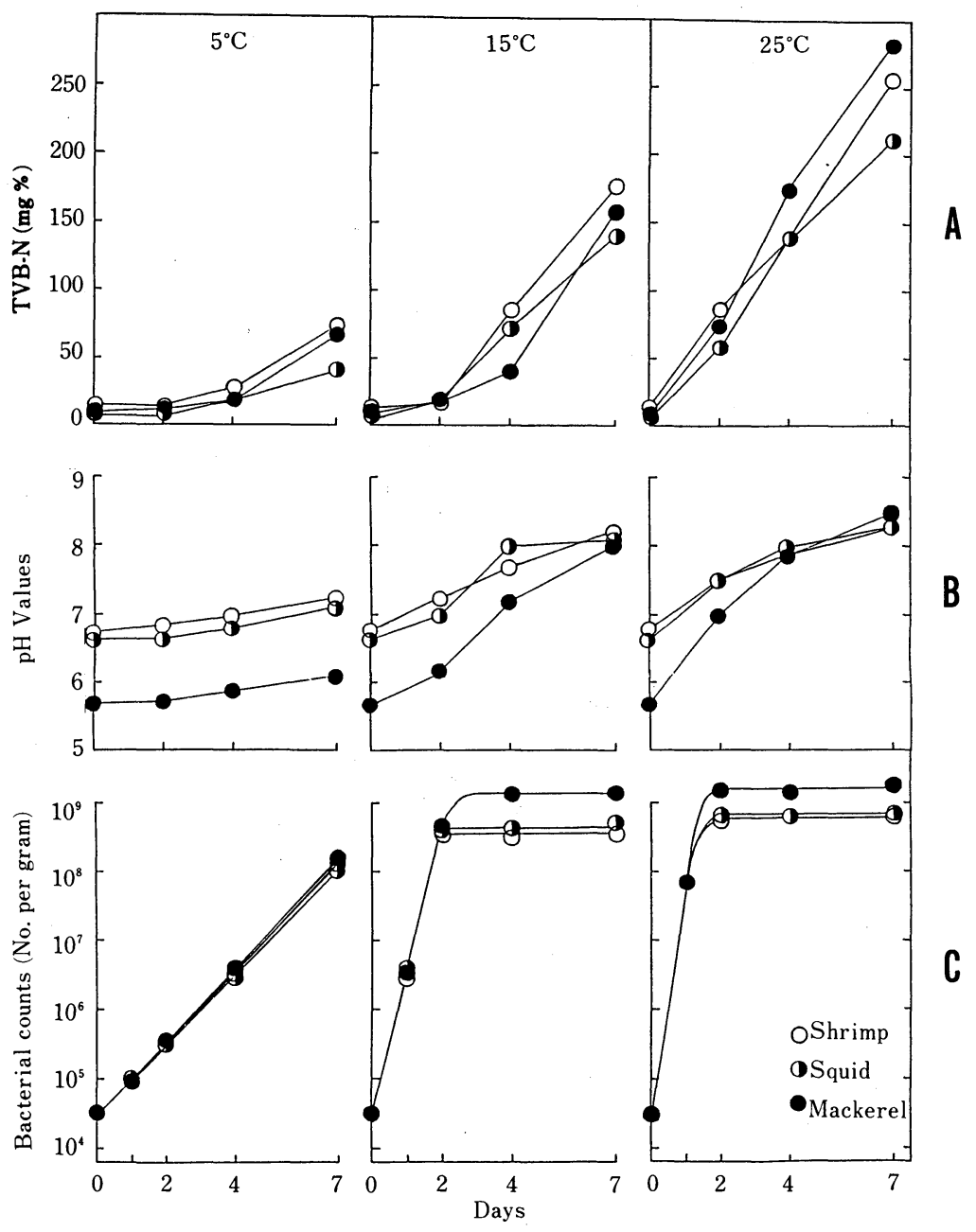

Fig. 3. Time courses of bacterial counts, $\mathrm{pH}$ values, and TVB-N values in 3 kinds of seafood samples inoculated with $P$. fluorescens, and incubated at 5,15 and $25^{\circ} \mathrm{C}$ for up to 7 days.

A: TVB-N; B: pH values; C: bacterial counts

増殖曲線よりは 2 オーダー減少し，7 日目には S. epidermidis は死滅した。

\section{7 . 混合接種 3 週間保存後の各菌種の消長}

混合接種 3 週間保存後の $5^{\circ}, 15^{\circ}, 25^{\circ}$ に打ける各菌種 の増殖曲線を Fig. 6 に示した.

C. lipolytica の生残性が最も高く, $5^{\circ}, 15^{\circ}$ 及び $25^{\circ}$ 保 存のサバ, エビ, イカでは本菌の定常期の菌数 $\left(10^{7}\right.$ $\left.10^{8}\right)$ のままで生残していた。 しかし P. fluorescens は $5^{\circ}$, $15^{\circ}, 25^{\circ}$ と保存温度が高くなるに従って生残菌数は減少 した.

\section{考 察}

酵母 C. lipolytica 及び細菌 P. fluorescens, S. epidermidis 単独接種の初発菌数は 3 菌種とも $10^{4}$ のオーダー であったが， C. lipolytica の細胞") $(2 \sim 4.5 \mu \times 4 \sim 22 \mu)$
は大きく, 增殖速度が遅いため, $25^{\circ}$ 保存, 2 日目の生菌 数 $\left(10^{6} / \mathrm{g}\right)$ は, 細菌より $2 \sim 3$ オーダーも低かった. しか し, 各 3 菌種により生成される VBN 量を同条件で比較 すると，酵母による生成量は，細菌によるそれらより少 ない量とはならなかった。 また，C. lipolytica の生育は 遅いが，急速に生育する P. fluorescens 之同様に保存日 数の短い時点で, すなわち $25^{\circ}$ 保存では 2 日目, $15^{\circ}$ 保 存では 4 日目には初期腐敗値を越えた。

酵母 C. lipolytica は世代時間 ${ }^{10)}$ (約 90 120 分）が長 いため細菌とは異なった緩やかな增殖曲線を示した。酵 母または細菌の増殖曲線と，それに対応するVBN 曲線 を 3 菌種間 ( $25^{\circ}$ 保存) で比較してみると, まず, 細菌 $P$. fluorescens よ S. epidermidis 2 菌種間では, 両者 (Fig. 3, C; Fig. 2, C) の増殖曲線は類似しているにもかかわら 

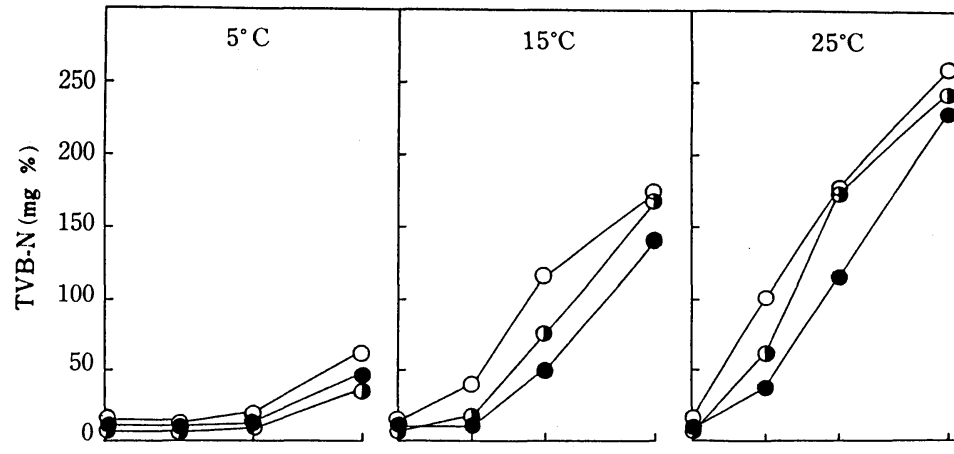

A
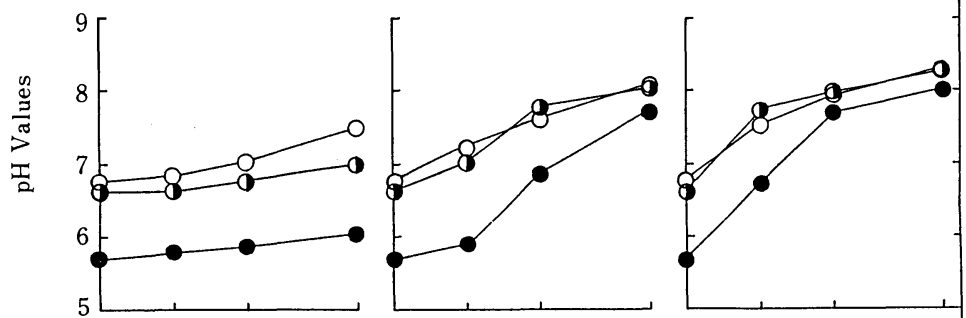

B
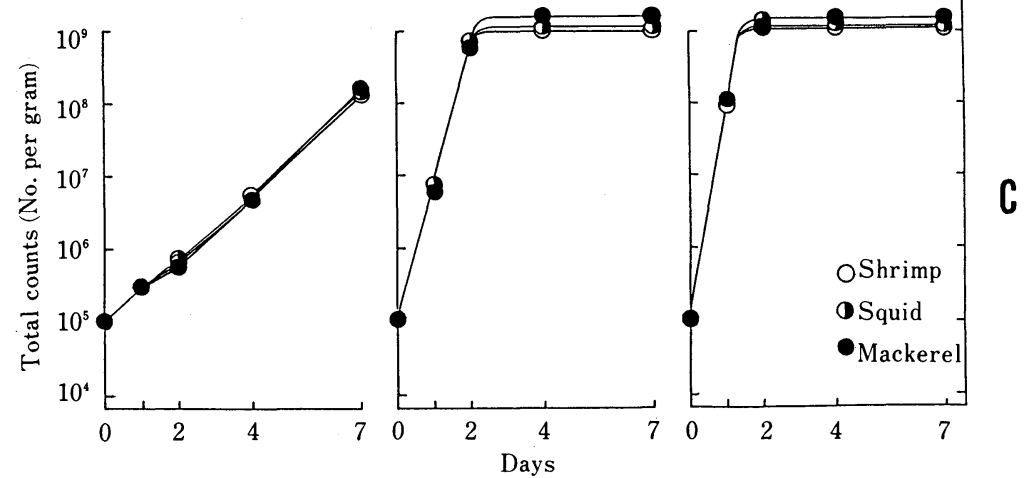

Fig. 4. Time courses of total counts, $\mathrm{pH}$ values, and TVB-N values in 3 kinds of seafood samples inoculated with a mixture containing C. lipolytica, S. epidermidis and P. fluorescens, and incubated at 5,15 and $25^{\circ} \mathrm{C}$ for up to 7 days.

A: TVB-N; B: $\mathrm{pH}$ values; C: total counts

ず, VBN の生成量は前者 (Fig. 3, A) の方が後者 (Fig. 2, A) よりは著しく多かった. 次に酵母 C. lipolytica と細菌 S. epidermidis 2 菌種間では, 増殖曲線の傾斜は前者 (Fig. 1,C) の方が，後者 (Fig. 2, C) よりは緩やかであっ たが，VBN 生成量は前者 (Fig. 1, A) の方が後者 (Fig. 2, A) より極めて多かった. また, 酵母 C. lipolytica と細菌 P. fluorescens 2 菌種間では, 増殖曲線の傾斜は前者 (Fig. 1,C) の方が後者 (Fig. 3，C) より緩やかであったが, 両者 (Fig. 1, A; Fig. 3, A) の VBN 曲線はほぼ類似して いた。このように酵母数または細菌数の増加と VBN 生 成量との間には必ずしも比例関係は成立しなかった。

C. lipolytica, P. fluorescens, S. epidermidis 3 菌種の混 合接種 1 週間保存における各 3 菌種別の生育状態をみ
ると，優勢菌種である C. lipolytica (Fig. 5, E) とP. fluorescens (Fig. 5, D) は，相互の生育に影響されること なく個々に増殖したが，S. epidermidis (Fig. 5, F) は 7 日目には死滅した。酵母と細菌 3 菌種の混合接種による VBN 曲線 (Fig. 4, A) は, 酵母 C. lipolytica (Fig. 1, A) ま たは細菌 P. fluorescens (Fig. 3, A) の単独接種時の VBN 曲線と類似していた。この結果は 3 菌種の細菌P Pseudomonas schulkilliensis, Micrococcus nitrificans, 連鎖 状乳酸球菌の混合培養における VBN 曲線が，優勢菌種 であるP. schulkilliensis 単独培養時の VBN 曲線と類似 していたという中島 ${ }^{11}$ の結果と同様であった.

要 約

酵母 C. lipolytica 及び細菌 S. epidermidis, P. fuo- 


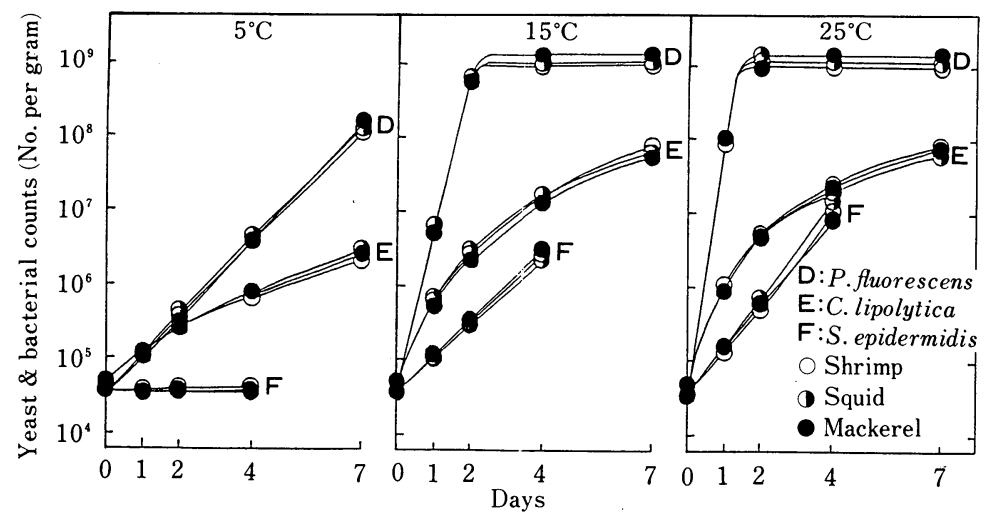

Fig. 5. Individual yeast and bacterial counts in 3 kinds of seafood samples inoculated with a mixture containing C. lipolytica, S. epidermidis and P. fluorescens, incubated at 5, 15 and $25^{\circ} \mathrm{C}$ for up to 7 days

These growth curves correspond with the total counts as in Fig. 4.

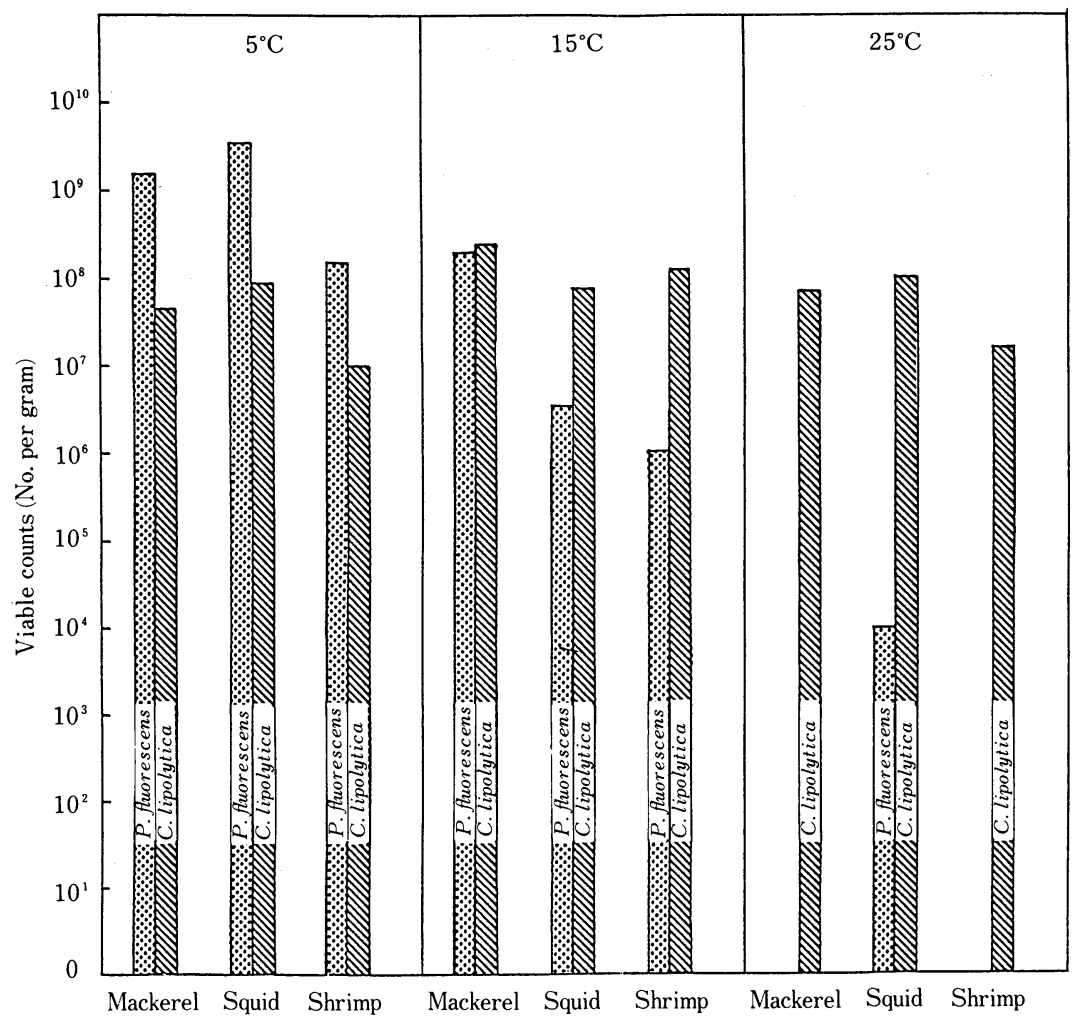

Fig. 6. Individual yeast and bacterial counts in 3 kinds of seafood samples inoculated with a mixture containing $C$. lipolytica, S. epidermidis and P. fluorescens, and incubated at 5, 15 and $25^{\circ} \mathrm{C}$ for 3 weeks

Viable counts after incubation for 3 weeks as in Fig. 5.

$\mathbb{Q}$ : C. lipolytica; ; P. fluorescens 
rescens の 3 菌種をサバ, エビ, イカの 3 種滅菌ホモジ ネートに単独または混合接種し, それぞれ $5^{\circ}, 15^{\circ}, 25^{\circ}$ で保存した場合の生菌数, VBN 值, $\mathrm{pH}$ 值を保存 $0,2,4$, 7 日目に測定した。 また, 混合接種 3 週間保存後におけ る各菌種の生残菌数を測定した。

1. S. epidermidis 単独接種の $25^{\circ}$ 保存, 2 日目の生 菌数は著しく增加し, $10^{8} \mathrm{cfu} / \mathrm{g}$ となったが, VBN 值は 極めて低く初期腐敗値以下であった。本菌は被験 3 菌種 の中では最も腐敗力の弱い菌種であった。

2. P. fluorescens をサバに接種し, $5^{\circ}, 15^{\circ}, 25^{\circ}$ で 7 日間保存した場合の VBN 值は，それぞれ 65.3，158.7， $283.3 \mathrm{mg}-\mathrm{N} /$ サバ $100 \mathrm{~g}$ であり, C. lipolytica よりやや 高く, S. epidermidis よりは著しく高い值を示した.

3. C. lipolytica 単独接種の增殖曲線は細菌のそれら とは異なり，緩やかな曲線を示した，本菌をサバに単独 接種し， $5^{\circ}, 15^{\circ}, 25^{\circ}$ で 7 日間保存した場合の VBN 値 は，それぞれ 32.7, 149.3, $260.0 \mathrm{mg}-\mathrm{N} /$ サバ $100 \mathrm{~g}$ であ り P. fluorescens よりやや低かったが, S. epidermidis よりは著しく高い值を示した。

4. 酵母人細菌の単独接種における生菌数測定値, VBN 值, $\mathrm{pH}$ 值は保存温度の上昇, 及び保存日数の経過 に伴って増加した. VBN 曲線と $\mathrm{pH}$ 曲線の間には, ほぼ 比例的な関係が認められたが, 増殖曲線と VBN 曲線と の間には必ずしも比例関係は認められなかった。

5. 酵母と細菌 3 菌種の混合接種 1 週間保存に招け る各菌種別の増殖状態は, 酵母 C. lipolytica と細菌 $P$. fluorescens が, 相互の生育に影響されることなく優勢に
増殖し, 細菌S. epidermidis は 7 日目には死滅した。

6 . 酵母之細菌 3 菌種の混合接種 3 週間保存後の各 菌種の生残性は, 酵母 C. lipolytica が最も高く, $5^{\circ}, 15^{\circ}$, $25^{\circ}$ のいずれの保存温度においても定常期の菌数を保持 していた。これに対し, P. fluorescens は $5^{\circ}, 15^{\circ}, 25^{\circ}$ と 保存温度が高くなるに従って生残菌数は隇少した。

\section{文献}

1）小畠満子, 外海泰秀, 小林加代子, 伊藤誉志男: 食衛誌. 28, 19 29 (1987).

2）小甶満子, 倉田 浩: 同上 21, 197 206 (1980).

3）小甶満子, 倉田 浩: 同上 24, 525 531 (1983).

4）小搨満子, 倉田 浩: 同上 24, 532 539 (1983).

5）小畠満子, 外海泰秀, 伊藤誉志男：同上 $28,30 \sim 35$ (1987).

6）厚生省環境衛生局監修：“食品衛生検查指針”（I） p. 103 106 (1973), 日本食品衛生協会.

7）外海泰秀, 伊藤誉志男, 原田基夫：食衛誌. $25,149 \sim 157$ (1984).

8）愿生省環境衛生局監修：“食品衛生検査指針”（II) p. 204 213 (1978) 日本食品衛生協会.

9) Kreger-van Rij, N. J. W., ed.: "The Yeasts, A taxonomic Study," 3rd ed., p. 406 408 (1984), Elsevier Science Publishers B. V., Amsterdam.

10) Phaff, H. J., Miller, M. W., Mark, E. M.: "The Life of Yeasts" 2nd ed., p. 52 58 (1978), Harvard Univ. Press, Cambridge, Massachusetts and London, England.

11）中島正博：腐研報. $2,4 \sim 35$ (1949). 